FINANCIAL: Jurnal Akuntansi

Published by Program Studi Akuntansi STIE Sultan Agung Volume 6-Nomor 2, Desember 2020, (HIm 227-236)

ISSN-P: 2502-4574, ISSN-E: 2686-2581

Available online at: https://financial.ac.id/index.php/financial

\title{
PENGARUH PERTUMBUHAN PERUSAHAAN, KEBIJAKAN DIVIDEN, GOOD CORPORATE GOVERNANCE TERHADAP NILAI PERUSAHAAN PADA PERUSAHAAN INDUSTRI BARANG KONSUMSI YANG TERDAFTAR DI BEI
}

\author{
Rika Kartika ${ }^{1)}$, Ibrohim $^{2)}$, Sona ${ }^{3)}$ \\ ${ }^{1,2,3}$ Program Studi Akuntansi, Universitas Bina Bangsa, Jalan Raya Serang - Jakarta, KM. 03 No. 1B, \\ Panancangan, Kec. Cipocok Jaya, Kota Serang, Banten 42124 \\ Email: ${ }^{1}$ rikakartika.binabangsa@gmail.com, ${ }^{2}$ ibrohim.binabangsa@gmail.com, ${ }^{3}$ ssitepu55@ gmail.com
}

\begin{abstract}
Abstrak
Nilai perusahaan tahun 2017-2019 terus mengalami penurunan. Penurunan nilai perusahaan juga diikuti dengan penurunan aset perusahaan. Disisi lain, perusahaan memiliki rasio pembayaran dividen yang terus meningkat. Selain itu penerapan good corporate governance dalam perusahaan masih belum maksimal.Tujuan penelitian ini adalah untuk mengetahui dan menganalisis pengaruh pertumbuhan perusahaan, kebijakan dividen dan good corporate governance terhadap nilai perusahaan pada perusahaan manufaktur sektor industri barang konsumsi yang terdaftar di Bursa Efek Indonesia periode 2015-2019, baik secara parsial maupun simultan. Penelitian ini menggunakan metode kuantitatif. Teknik pengambilan sampel menggunakan purposive sampling, sehingga diperoleh sampel sebanyak 78 data. Data dianalisis menggunakan regresi linier berganda dengan program SPSS 26. Hasil penelitian menunjukkan pertumbuhan perusahaan tidak berpengaruh terhadap nilai perusahaan, kebijakan dividen berpengaruh terhadap nilai perusahaan, proporsi dewan komisaris independen berpengaruh terhadap nilai perusahaan, ukuran komite audit tidak berpengaruh terhadap nilai perusahaan. Pertumbuhan perusahaan, kebijakan dividen, proporsi dewan komisaris independen dan ukuran komite audit berpengaruh secara simultan terhadap nilai perusahaan.
\end{abstract}

Kata Kunci: Pertumbuhan Perusahaan, Kebijakan Dividen, Good Corporate Governance, Nilai Perusahaan

\section{THE EFFECT OF COMPANY GROWTH, DIVIDEND POLICY, GOOD CORPORATE GOVERNANCE ON COMPANY VALUE IN REGISTERED CONSUMPTION GOODS INDUSTRY COMPANIES ON THE IDX}

\begin{abstract}
The value of the company in 2017-2019 continues to decline. The decline in company value was also followed by a decrease in the company's assets. On the other hand, the company has an increasing dividend payout ratio. The implementation of good corporate governance is still not optimal. This study aims to test, identify, and partially and simultaneously analyze the effect of company growth, dividend policy and good corporate governance on firm value in the consumer goods industry sector listed on the Indonesia Stock Exchange 2015 2019. The research method used is quantitative methods. In determining the sample, the technique used is purposive sampling. The number of samples is 78 company data. The data analysis used is multiple linear regression with SPSS 26 program. The results showed that company growth has no effect on firm value, dividend policy has an effect on firm value, the proportion of independent board of commissioners has an effect on firm value, the size of the audit committee has no effect on firm value. Company growth, dividend policy, the proportion of independent commissioners and the size of the audit committee simultaneously influence firm value.

Keywords: Company Growth, Dividend Policy, Good Corporate Governance, Company Value
\end{abstract}

Article History: Received: 30 Nop 2020 Revised: 16 Des 2020 Accepted: 19 Des 2020 


\section{PENDAHULUAN}

Dalam upaya menghadapi persaingan dunia bisnis yang semakin ketat maka para pelaku bisnis berusaha untuk dapat mempertahankan dan mengembangkan bisnisnya agar dapat bersaing atau unggul dari pesaing. Salah satu orientasi perusahaan dalam menjalankan bisnisnya yaitu berusaha untuk memperoleh keuntungan yang semaksimal mungkin. Bukan hal yang mudah dalam menjalankan suatu bisnis jika tanpa modal atau dengan modal yang terbatas, sebab modal adalah sejumlah dana (dapat berupa nominal uang ataupun barang) yang digunakan untuk menjalankan keberlangsungan suatu bisnis, bahkan dapat juga digunakan untuk berinvestasi.

Melalui pasar modal para pelaku bisnis dapat bertemu, antara pemilik dana yang lebih dan pihak yang mencari dana. Pasar modal memperdagangkan aset keuangan yang jangka waktunya panjang, biasanya diatas satu tahun, contohnya saham dan obligasi. Melalui pemanfaatan sumber daya, tujuan entitas bisnis yaitu mendapatkan profit yang optimal. Selain profit oriented, entitas bisnis juga berusaha untuk meningkatkan nilai perusahaan agar dapat memberikan keuntungan bagi para pemegang sahan yang sudah menanamkan modal di dalam entitas bisnis (Wijaya, 2017:1).

Nilai perusahaan, merupakan variabel yang sangat penting bagi entitas bisnis. Rendah tingginya nilai perusahaan dapat ditentukan melalui seberapa besar para investor (pemegang saham) tertarik untuk menginvestasikan dananya. Nilai perusahaan sebagai ukuran untuk nilai pengembalian dana investasi milik investor. Menurut Harmono (2016) Nilai perusahaan yaitu pencapaian entitas bisnis yang dipandang dan dinilai oleh investor melalui nilai saham yang terbentuk. Indikator yang digunakan untuk mengukur nilai perusahaan pada penelitiaan saat ini yaitu Price Book Value. Price Book Value (PBV) adalah harga saham per lembar dibagi nilai buku ekuitas per lembar saham (Husnan dan Pudjiastuti, 2015:84). Menurut Jogiyanto (2003:79), umumnya jika nilai PBV lebih besar dari satu, yang menunjukkan bahwa nilai pasar saham lebih besar daripada nilai buku perusahaan. Jika nilai PBV meningkat maka semakin baik pandangan investor terhadap kinerja perusahaan tersebut sehingga dapat meningkatkan minat investor untuk berinvestasi Sebaliknya, rendahnya nilai PBV dapat menurunkan tingkat keprcayaan investor pada kinerja perusahaan, sehingga investor pun enggan untuk berinvestasi . Rata-rata nilai perusahaan dapat dilihat pada Gambar 1 dibawah ini.

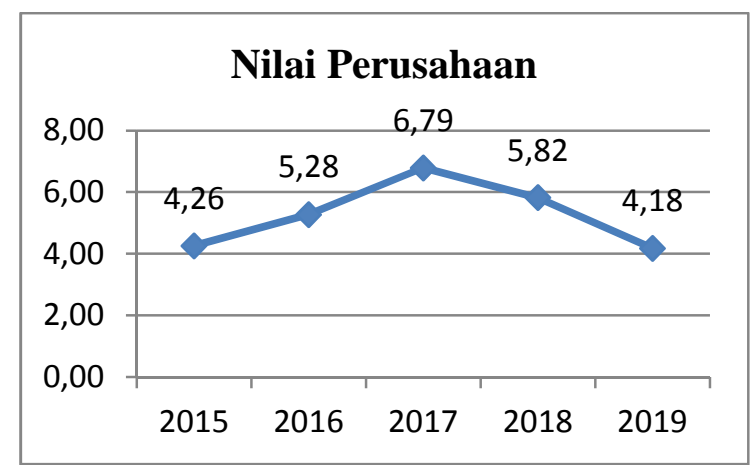

Sumber: Data diolah, 2020

Gambar 1

Grafik Rata-rata Nilai Perusahaan

Berdasarkan gambar grafik diatas menunjukkan bahwa rata-rata nilai PBV meningkat dari tahun 2015 - 2017, tetapi mulai tahun 2017 ke tahun 2018 nilai perusahaan (PBV) mengalami penurunan dan di tahun 2019 nilai rata-rata PBV mengalami penurunan yang cukup tajam. Terjadinya penurunan nilai perusahaan ini menarik untuk diteliti. 
Beberapa faktor internal yang mempengaruhi nilai perusahaan yaitu, kebijakan dividen dan good corporate governance dimana faktor-faktor ini sering digunakan oleh calon investor dalam menilai kemampuan perusahaan untuk mencapai nilai perusahaan yang tinggi. Pertumbuhan adalah naik turunnya volume usaha yang tercermin dari arus dana perusahaan (Helfert, 1997). Aset digunakan perusahaan untuk operasional perusahaan, dari total aset perusahaan dapat mengukur tingkat pertumbuhan perusahaan. Dalam penelitian ini, indikator yang digunakan dalam pertumbuhan perusahaan yaitu pertumbuhan aset. Grafik rata-rata nilai pertumbuhan perusahaan adalah sebagai berikut.

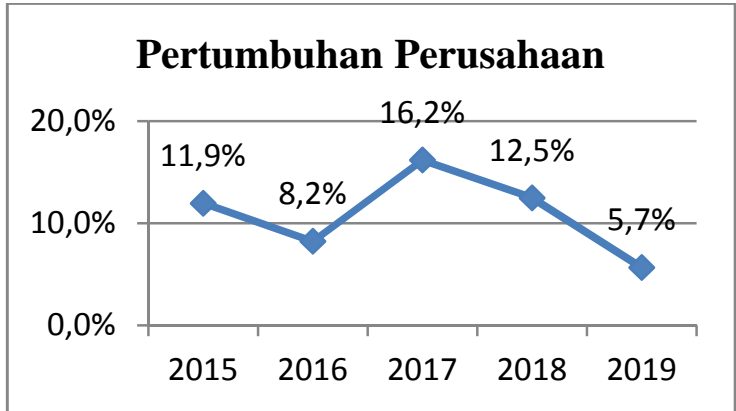

Sumber: Data diolah, 2020

Gambar 2.

Grafik Rata-Rata Pertumbuhan Perusahaan

Hasil penelitian Suryandani (2018 : 56 ) menunjukkan bahwa adanya pengaruh pertumbuhan perusahaan terhadap nilai perusahaan. Sedangkan penelitian Erawati \& Sihaloho (2019 : 127 )menunjukkan bahwa tidak adanya pengaruh pertumbuhan perusahaan terhadap nilai perusahaan pada perusahaan manufaktur sub sektor makanan dan minuman.

Harga saham dipengaruhi oleh jumlah dividen, tinggi rendahnya dividen yang diterima oleh investor sebandinng dengan nilai perusahaan. Jika dividen tinggi, maka nilai perusahanpun dapat meningkat, dan sebaliknya. Pada saat modal investor ditanamkan pada perusahaan, maka investor mendambakan mendapatkan return yang menguntungkan atas investasinya. Kebijakan dividen yaitu keputusan apakah laba yang diperoleh perusahaan akan dibagikan kepada pemegang saham sebagai dividen atau akan ditahan dalam bentuk laba ditahan yang digunakan untuk membiayai investasi masa mendatang (Musthafa, 2017 : 141 ).

Proksi kebijakan dividen dalam pengujian ini menggunakan Dividend Payout Ratio (DPR).Dividen Payout Ratio adalah dividen yang dibayar dibagi laba bersih (Musthafa, 2017 : 30). Dibawah ini gambar 3 yaitu grafik rata-rata kebijakan dividen.

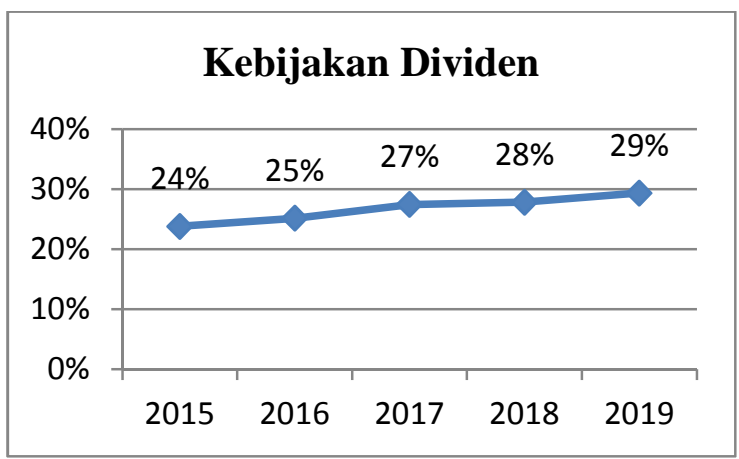

Sumber: Data diolah, 2020

Gambar 3.

Grafik Rata-Rata Kebijakan Dividen

Penelitian Lolowang \& Hastuti (2019) menunjukkan bahwa kebijakan dividen tidak berpengaruh terhadap nilai perusahaan. Penelitian yang dilakukan oleh Erawati \& Sihaloho (2019) nilai perusahaan dipengaruhi oleh kebijakan dividen. Nilai perusahaan dapat dikatakan baik apabila menerapkan Good Corporate Governance. Indikator good corporate governance yaang digunakan dalam pengujian dan penelitian ini yaitu proporsi 
dewan komisaris independen dan ukuran komite audit

.Komisaris independen adalah anggota komisaris yang tidak mempunyai hubungan afiliasi dengan anggota komisaris lainnya. Anggota komisaris independen yaitu minimal tiga puluh persen dari keseluruhan jumlah komisaris, Samsul (2006 :72). Grafik nilai rata-rata Proporsi Dewan Komisaris Independen dapat dilihat pada Gambar 4.

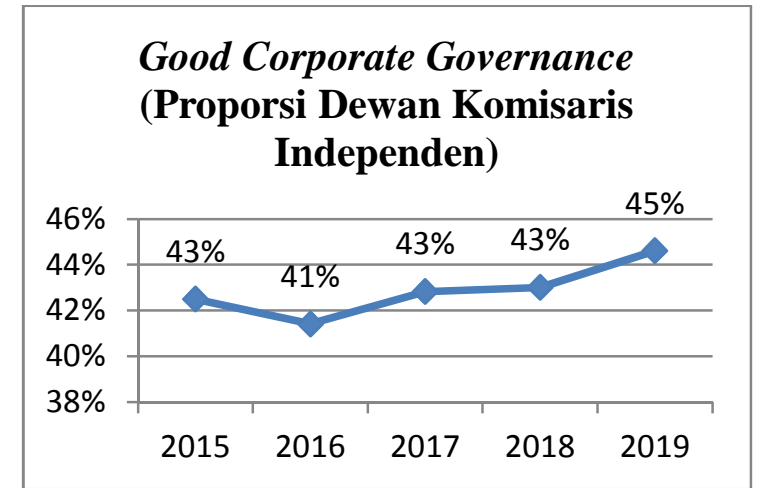

Sumber: Data diolah, 2020

Gambar 1. Grafik Rata-rata Dewan

Komisaris Independen

Penelitian Kumalasari dan Widyawati (2017) menunjukkan hasil bahwa komisaris independen memiliki pengaruh dengan nilai perusahaan. Hasil penelitian Amaliyah dan Herwiyanti (2019) menyimpulkan bahwa dewan komisaris independen tidak berpengaruh terhadap nilai perusahaan. Dibawah ini Grafik nilai rata-rata Ukuran Komite Audit.

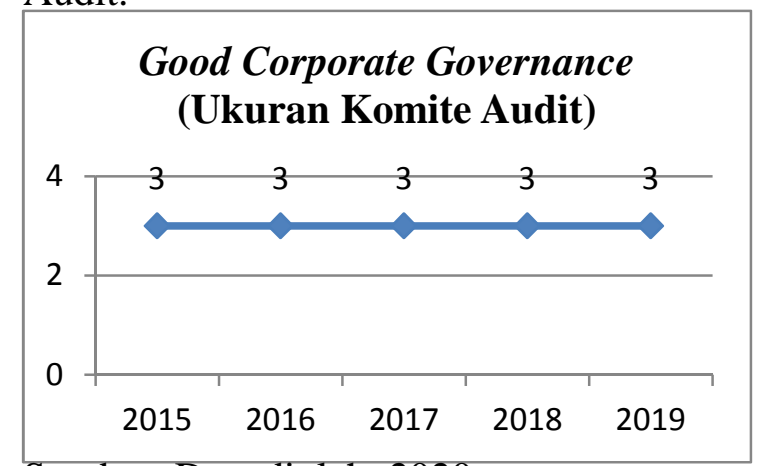

Sumber: Data diolah, 2020

Gambar 5

Grafik Rata-Rata Ukuran Komite Audit

Copyright (C) 2020, FINANCIAL: Jurnal Akuntansi
Komite audit bertugas mengontrol aktivitas perusahaan termasuk dalam mengawasi laporan keuangan perusahaan agar dapat dipastikan tidak adanya penyelewengan (Samsul, 2006). Berdasarkan hasil penelitian Amaliyah Herwiyanti (2019) menunjukkan bahwa komite audit mempunyai pengaruh positif terhadap nilai perusahaan. Hasil penelitian Kumalasari dan Widyawati (2017) yang menyimpulkan bahwa komite audit tidak berpengaruh terhadap nilai perusahaan.

Penelitian ini menggunakan perusahaan manufaktur sektor industri barang konsumsi yang terdaftar di Bursa Efek Indonesia sebagai populasi, sebab industri barang konsumsi (consumer goods) merupakan produsen barangbarang yang menjadi kebutuhan prioritas bagi masyarakat. Berdasarkan uraian diatas maka mengangkat penelitian ini dengan judul "Pengaruh Pertumbuhan Perusahaan, Kebijakan Dividen Dan Good Corporate Governance Terhadap Nilai Perusahaan (Studi Kasus Pada Perusahaan Manufaktur Sektor Industri Barang Konsumsi Yang Terdaftar Di Bursa Efek Indonesia Periode 2015-2019)".

\section{LANDASAN TEORI}

\section{Nilai Perusahaan}

Menurut Harmono (2016: 233), Nilai perusahaan merupakan pencapaian entitas bisnis yang dipandang dan dinilai oleh investor melalui nilai saham yang terbentuk. Price Book Value (PBV) adalah harga saham per lembar dibagi nilai buku ekuitas per lembar saham (Husnan dan Pudjiastuti, 2015:84).

$$
\mathrm{PBV}=\frac{\text { Harga Saham Per Lembar }}{\text { Nilai Buku Ekuitas Per Lbr Saham }}
$$




\section{Pertumbuhan Perusahaan}

Menurut Brigham, Houston (2009), pertumbuhan perusahaan adalah adalah perubahan (peningkatan atau penurunan) dari total aset yang dimiliki perusahaan selama satu periode (satu tahun). Menurut Prasetyo (2011: 110-118), indikator dalam pertumbuhan perusahaan terdiri dari empat yaitu asset, penjualan, laba bersih dan laba kotor. Pertumbuhuan aset dapat dirumuskan sebagai berikut:

$$
=\frac{\begin{array}{c}
\text { Pertumbuhan Aset } \\
\text { total aset }_{\mathrm{t}}-\text { total ase }_{\mathrm{t}-1}
\end{array}}{\text { total aset }_{\mathrm{t}-1}}
$$

\section{Kebijakan Dividen}

Menurut Sugeng (2017:402), kebijakan dividen adalah penetapan berapa besarnya dividen atau bagian keuntungan yang akan dibagikan sebagian dividen dan berapa yang sebaiknya ditahan di perusahaan untuk memenuhi kebutuhan dana oleh perusahaan, serta bagaimana pola pendistribusiannya. Indikator kebijakan dividen dalam penelitian ini menggunakan Dividend Payout Ratio (DPR). DPR adalah dividen yang dibayar dibagi laba bersih (Musthafa, 2017).

$$
\text { Dividend Payout Ratio }=\frac{\text { Dividen }}{\text { Laba Bersih }}
$$

\section{Good Corporate Governance}

Sutedi (2011) mendefinisikan Corporate governance adalah suatu proses dan struktur yang digunakan oleh organ perusahaan (Pemegang Saham/Pemilik Modal, Komisaris/Dewan pengawas, dan Direksi) untuk meningkatkan keberhasilan usaha dan akuntabilitas perusahaan guna mewujudkan nilai pemegang saham dalam jangka waktu yang panjang serta tanpa mengabaikan stakeholder lainnya, sesuai aturan perundang-undangan yang berlaku dan menjunjung tinggi nilai etika.
Dalam menjalankan kegiatan usaha suatu perusahaan, prinsip good corporate governance dituangkan dalam suatu mekanisme. Adapun indikator pendukung mekanisme good corporate governance yaitu dewan direksi, dewan komisaris, kepemilikan manajerial, dan kepemilikan institusional.

Komisaris independen menurut Agoes dan Ardana (2011:110) adalah seseorang yang ditunjuk untuk mewakili pemegang saham independen (pemegang saham minoritas) dan pihak yang ditunjuk tidak dalam kapasitas mewakili pihak manapun hanya fokus pada dasar wawasan, pengalaman, dan kemampuan profesional agar dapat melaksanakan tanggungjwab untuk perusahaan. Menurut Kumalasari dan Wdiyawati (2017) Proporsi Dewan Komisaris Independen dapat dirumuskan sebagai berikut:

Proporsi Dewan Komisaris Independen $=\frac{\text { Jlh komisaris independen }}{\text { Jlh anggota dewan komisaris }} \times 100 \%$

Menurut Sutedi (2011 :150) komite audit (audit committee) bertugas dalam pengawasan pelaporan keuangan. Menurut Rahmawati, Rikumahu, dan Dillak (2017) komite audit sama dengn jumlah seluruh komite audit.

Komite Audit $=$ EAnggota Komite audit

\section{Pengembangan Hipotesis}

Pengaruh Pertumbuhan Perusahaan Terhadap Nilai Perusahaan

Jika nilai aset perusahaan meningkat maka dapat berdampak pada hasil operasional perusahaan yang juga akan mengalami pergerakan peningkatan, sebanding dengan pencapaian keuntungan. Meningkatnya laba perusahaan akan mempengaruhi tingkat pengembalian 
investasi. Pertumbuhan perusahaan yang terus meningkat maka, saham perusahaan akan lebih diminati oleh investor. Semakin tinggi minat investor maka permintaan atas saham juga akan meningkat, sehingga akan mempengaruhi harga atas saham perusahaan, harga saham akan melonjak tinggi dan nilai perusahaan pun dapat mengalami peningkatan.

H1: Pertumbuhan perusahaan berpengaruh terhadap nilai perusahaan.

\section{Pengaruh Kebijakan Dividen Terhadap Nilai Perusahaan}

Dividen Payout Ratio (DPR) yang tinggi mencerminkan prospek perusahaan yang baik karena para investor akan tertarik dengan besarnya tingkat return. Jika permintaan investor atas saham meningkat, maka akan berbanding lurus dengan harga saham dan nilai perusahaan.

H2: Kebijakan dividen berpengaruh terhadap nilai perusahaan.

\section{Pengaruh Proporsi Dewan Komisaris Independen terhadap Nilai Perusahaan}
Adanya dewan komisaris

independen diharapkan dapat mengurangi tindakan fraud sehingga dapat meningkatkan kualitas laporan keuangan, maka dapat meningkatnya keinginan investor untuk berinvestasi, hal tersebut dapat mengakibatkan naiknya harga saham juga nilai perusahaan.

H3: Proporsi dewan komisaris independen berpengaruh terhadap nilai perusahaan

\section{Pengaruh Komite Audit terhadap Nilai Perusahaan}

Komite Audit bertugas untuk memeriksa Laporan keuangan perusahaan harus sesuai dengan standar akuntansi yang berlaku, maka yang terpublikasi laporan keuangan yang memiliki kualitas yang baik, oleh sebab itu maka dapat berdampak pada meningkatnya nilai perusahaan.

H4: Komite audit berpengaruh terhadap nilai perusahan

\section{Pengaruh Pertumbuhan Perusahaan,} Kebijakan Dividen, GCG (Proporsi Dewan Independen), GCG (Komite Audit) terhadap Nilai Perusahaan

Ketika aset perusahaan meningkat diprediksi pertumbuhan perusahaan akan meningkat, begitupun dapat membuat nilai perusahaan ikut meningkat. Kebijakan dividen yang diukur dengan Dividen Payout Ratio (DPR), jika DPR meningkat, maka nilai perusahaan dapat meningkat. $G C G$ yang diterapkan dalam perusahaan dapat meningkatkan prestasi perusahaan. Dalam mekanismenya, dewan komisaris independen dan komite audit berperan penting dalam meningkatkan nilai perusahaan.

H5: Pertumbuhan perusahaan, kebijakan dividen, gcg (proporsi dewan independen), gcg (komite audit) berpengaruh terhadap nilai perusahan

\section{METODE PENELITIAN}

Objek dalam penelitian adalah Perusahaan Manufaktur Sektor Industri Barang Konsumsi Yang Terdaftar Di Bursa Efek Indonesia Periode 2015-2019. Populasi penelitian ini berjumlah 53 perusahaan dan sampeldalam penelitian ini sebanyak 17 perusahaan dengan tekink pengambilan sampel purposive sample. Jenis data penelitian ini adalah data kuantitatif dengan menggunakan sumber data sekunder. Teknik pengumpulan data dalam penelitian ini yaitu dokumentasi, 
dan teknis analisis data menggunakan regresi linier berganda dengan program SPSS 26.

\section{HASIL DAN PEMBAHASAN Hasil Penelitian}

Dalam penelitian ini ditambahkan dengan menggunakan model revisi, model revisi ini dibuat untuk menguji kembali asumsi klasik karena pada model awal terdapat salah satu uji yang terdapat masalah gejala heteroskedastisitas sehingga perlu dilakukan penyembuhan dengan cara mentransform semua variabel baik independen maupun dependen dengan menggunakan logaritma natural (Ln), sehingga sampel penelitian ini menjadi 78 data dari 85 data.

\section{Analisis Regresi Linear Berganda}

Tujuan analisis regresi linear berganda adalah untuk menguji pengaruh pertumbuhan perusahaan (growth), kebijakan dividen (DPR), good corporate governance (proporsi dewan komisaris independen dan ukuran komite audit) terhadap nilai perusahaan (PBV). Hasil dari regresi linier berganda adalah sebagai berikut :

Tabel 1.

Hasil Analisis Regresi Linier Berganda

\begin{tabular}{|c|c|c|c|c|c|}
\hline \multicolumn{6}{|c|}{ Coefficients $^{\mathrm{a}}$} \\
\hline Model & B & $\begin{array}{l}\text { Std. } \\
\text { Error }\end{array}$ & Beta & $\mathrm{T}$ & Sig. \\
\hline 1 (Constant) & 1.721 & 1.553 & & 1.108 & .271 \\
\hline Ln_Growth & .121 & .122 & .092 & .998 & .322 \\
\hline Ln_DPR & .957 & .171 & .542 & 5.607 & .000 \\
\hline Ln_PDKI & 1.595 & .483 & .312 & 3.300 & .001 \\
\hline Ln_UKA & 1.842 & 1.306 & .126 & 1.410 & .163 \\
\hline
\end{tabular}

Persamaan regresi liner berganda yang dapat disusun yaitu sebagai berikut:

$$
\begin{gathered}
\mathrm{Y}=1,721+0,121 \mathrm{X} 1+0,957 \mathrm{X} 2+ \\
1,595 \mathrm{X} 3+1,842 \mathrm{X} 4
\end{gathered}
$$

Keterangan:

$$
\begin{array}{ll}
\text { Y } & \text { : Nilai Perusahaan } \\
\text { X1 } & \text { : Pertumbuhan Perusahaan } \\
\text { X2 } & \text { : Kebijakan Dividen } \\
\text { X3 } & \text { : Proporsi Komisaris Independen } \\
\text { X4 } & \text { : Ukuran Komite audit }
\end{array}
$$

\section{Uji Parsial (Uji t)}

Uji t yaitu untuk menguji variabel independen terhadap variabel dependen secara parsial. Jika signifikansi lebih dari 0,05 atau $t_{\text {hitung }}>t_{\text {tabel }}$ maka terdapat pengaruh variabel independen terhadap variabel dependen, dan sebaliknya Hasil dari uji $\mathrm{t}$ untuk masing-masing variabel bebas dapat dilihat pada Tabel 2 berikut:

\section{Tabel 2. Hasil Uji t}

Sumber: Data diolah (2020)

\begin{tabular}{cc|c|c|c|c}
\multicolumn{7}{c}{ Coefficients $^{\mathrm{a}}$} \\
Model & B & Std. & & & \\
\hline 1 Error & Beta & T & Sig. \\
\hline (Constant) & 1.721 & 1.553 & & 1.108 & .271 \\
\hline Ln_Growth & .121 & .122 & .092 & .998 & .322 \\
\hline Ln_DPR & .957 & .171 & .542 & 5.607 & .000 \\
\hline Ln_PDKI & 1.595 & .483 & .312 & 3.300 & .001 \\
\hline Ln_UKA & 1.842 & 1.306 & .126 & 1.410 & .163 \\
\hline a. Dependent Variable: Ln_PBV & & &
\end{tabular}

Berdasarkan tabel output SPSS yang disajikan pada Tabel 2 diketahui bahwa:

Hipotesis Pertama (H1)

Pertumbuhan perusahaan dengan proksi Growth asset diketahui nilai sig $=0,322$ dan $t_{\text {hitung }}=0,998$. Jika dibandingkan dengan $t_{\text {tabel }}=1,993$ maka $0,998<1,993$ dan 0,322> 0,05. Sehingga, pertumbuhan perusahaan tidak berpengaruh terhadap nilai perusahaan $\left(\mathrm{H}_{1}\right.$ di tolak).

Hipotesis Kedua (H2)

Pada variabel kebijakan dividen diketahui nilai sig $=0,000$ dan $t_{\text {hitung }}=5,607$. Jika dibandingkan dengan $\mathrm{t}_{\text {tabel }}=1,993$ maka $5,607>1,993$ dan $0,000<0,05$. Sehingga, kebijakan dividen berpengaruh terhadap nilai perusahaan $\left(\mathrm{H}_{2}\right.$ di terima).

Hipotesis ketiga (H3) 
Pada variabel proporsi dewan komisaris independen diketahui nilai sig $=0,001$ dan $\mathrm{t}_{\text {hitung }}=3,300$. Jika dibandingkan dengan $\mathrm{t}_{\text {tabel }}=1,993$ maka 3,300>1,993 dan 0,001 $<0,05$. Sehingga, variabel proporsi dewan komisaris independen berpengaruh terhadap nilai perusahaan $\left(\mathrm{H}_{3}\right.$ di terima).

Hipotesis Keempat (H4)

Pada variabel komite audit diketahui nilai sig $=0,551$ dan $t_{\text {hitung }}=1,410$. Jika dibandingkan dengan $t_{\text {tabel }}=1,993$ maka $1,410<1,993$ dan 0,551>0,05. Sehingga, variabel komite audit tidak berpengaruh terhadap nilai perusahaan $\left(\mathrm{H}_{4}\right.$ di tolak).

\section{Uji Simultan (Uji F)}

Uji $F$ bertujuan untuk menguji apakah semua variabel bebas berpengaruh terhadap variabel terikat. Jika nilai sig < 0,05 atau $F_{\text {hitung }}>F_{\text {tabel }}$ maka terdapat pengaruh variable bebas terhadap variabel terikat secara simultan, dan sebaliknya. Hasil uji statistik $F$ dapat dilihat pada Tabel 3 di bawah ini:

\section{Tabel 3. Hasil Uji F}

\begin{tabular}{cc|c|c|c|c|c}
\multicolumn{7}{c}{ ANOVA $^{\mathrm{a}}$} \\
Model & $\begin{array}{c}\text { Sum of } \\
\text { Squares }\end{array}$ & Df & $\begin{array}{c}\text { Mean } \\
\text { Square }\end{array}$ & F & Sig. \\
\hline 1 Regression & 44.857 & 4 & 11.214 & 15.396 & $.000^{\mathrm{b}}$ \\
\hline Residual & 53.173 & 73 & .728 & & \\
\hline Total & 98.030 & 77 & & & \\
\hline
\end{tabular}

a. Dependent Variable: Ln_PBV

b. Predictors: (Constant), Ln_UKA, Ln_PDKI, Ln_Growth, Ln_DPR

Sumber : Hasil data diolah (2020)

\section{Pembahasan}

\section{Pengaruh Pertumbuhan Perusahaan terhadap Nilai Perusahaan}

Berdasarkan perhitungan spss menunjukan bahwa tidak terdapat pengaruh antara pertumbuhan perusahaan yang diproksikan dengan growth asset terhadap nilai perusahaan yang diproksikan dengan price book value. Tingginya pertumbuhan aset milik perusahaan, akan berdampak kepada kebutuhan dana yang semakin meningkat untuk mengelola kegiatan operasional perusahaan karena perusahaan cenderung memilh untuk tidak mengeluarkan laba sebab perusahaan mengalokasikannya untuk mendanai kebutuhaan pertumbuhan dari perusahaan.Hal ini yang menyebabkan menurunnya kepercayaan investor dalam menginvestasikan dananya di perusahaan sehingga mengakibatkan nilai perusahaan ikut menurun.

\section{Pengaruh Kebijakan Dividen terhadap Nilai Perusahaan}

Berdasarkan hasil penelitian menunjukan bahwa DPR berpengaruh signifikan terhadap nilai perusahaan (price book value), sebab besarnya pembagian dividen kepada investor akan menambah kepercayaan pemegang saham dan menjadi daya tarik bagi investor dalam menginvestasikan dananya, maka dapat meningkatkan harga saham dan nilai perusahaan.

\section{Pengaruh Proporsi Komisaris Independen terhadap Nilai Perusahaan}

Berdasarkan hasil pengujian menunjukan bahwa good corporate governance (proporsi konisaris independen) memiliki pengaruh terhadap nilai perusahaan. Upaya untuk meningatkan kualitas pelaporan keuangan dibutuhkan adanya efektifitas dalam pengawasan sehingga adanya komisaris independen sangat diperlukan di dalam perusahaan. Laporan keuangan yang berkualitas dapat menyebabkan investor lebih yakin untuk menanamkan modalnya di perusahaan tersebut, sehingga pada umumnya harga saham perusahaan akan meningkat, begitupun dengan nilai perusahaan menjadi tinggi.

\section{Pengaruh Ukuran Komite Audit terhadap Nilai Perusahaan}

GCG dengan proksi komite audit tidak memiliki pengaruh terhadap nilai perushaaan. Banyaknya anggota komite audit bukan merupakan jaminan bahwa kinerja suatu perusahaan akan membaik, 
sehingga ukuran komite audit bukan menjadi bahan pertimbangan investor sehingga tidak mempengaruhi nilai perusahaan.

\section{Pengaruh Pertumbuhan Perusahaan, Kebijakan Dividen, Proporsi Dewan Komisaris Independen, dan Ukuran Komite Audit Terhadap Nilai Perusahaan}

Secara simultan terdapat pengaruh pertumbuhan perusahaan, kebijakan dividen, proporsi dewan komisaris independen, dan ukuran komite audit terhadap nilai perusahaan pada perusahaan manufaktur sektor industri barang konsumsi yang terdaftar di Bursa Efek Indonesia periode 2015-2019. Analisis data tersebut menunjukan bahwa pertumbuhan perusahaan, kebijakan dividen, proporsi dewan komisaris independen, dewan direksi dan komite audit akan mempengaruhi besarnya nilai perusahaan pada perusahaan manufaktur sektor industri barang konsumsi di BEI periode 20159-2019.

\section{SIMPULAN DAN SARAN}

Simpulan

Hasil penelitian menunjukkan bahwa tidak terdapat pengaruh pertumbuhan perusahaan terhadap nilai perusahaan pada perusahaan manufaktur Sektor Industri Barang Konsumsi yang terdaftar di Bursa Efek Indonesia Periode 2015-2019.

Hasil penelitian menunjukkan bahwa kebijakan dividen memiliki pengaruh terhadap nilai perusahaan pada perusahaan manufaktur Sektor Industri Barang Konsumsi yang terdaftar di Bursa Efek Indonesia Periode 2015-2019.

Hasil penelitian ini menunjukkan bahwa proporsi dewan komisaris independen berpengaruh terhadap nilai perusahaan pada perusahaan manufaktur Sektor Industri Barang Konsumsi yang terdaftar di Bursa Efek Indonesia Periode 2015-2019.
Hasil penelitian ini menunjukkan bahwa tidak terdapat pengaruh antara ukuran komite audit terhadap nilai perusahaan pada perusahaan manufaktur Sektor Industri Barang Konsumsi yang terdaftar di Bursa Efek Indonesia Periode 2015-2019. Hal ini dibuktikan dengan menggunakan uji $\mathrm{t}$ yang menghasilkan nilaisig $=0,163$ dan $t_{\text {hitung }}=1,410$. Jika dibandingkan dengan $t_{\text {tabel }}=1,993$ maka $0,163<1,993$ dan $1,410>0,05$.

Diperoleh hasil penelitian bahwa pertumbuhan perusahaan, kebijakan dividen, proporsi dewan komisaris independen dan ukuran komite audit berpengaruh secara simultan terhadap nilai perusahaan pada perusahaan manufaktur Sektor Industri Barang Konsumsi yang terdaftar di Bursa Efek Indonesia Periode 2015-2019.

\section{Saran}

Untuk peneliti selanjutnya dapat menambah variabel independen lainnya, menambah indikator dari variabel good corporate governance dan menambahkan periode penelitian.

\section{DAFTAR PUSTAKA}

Agoes Sukrisno dan Ardana I Cenik. (2011). Etika Bisnis Dan Profesi. Salemba Empat.

Amaliyah Fitri, H. E. (2019). Pengaruh Kepemilikan Institusional, Dewan Komisaris Independen, Dan Komite Audit Terhadap Nilai Perusahaan Sektor Pertambangan. 9(3), 187-200.

Brigham, Houston, Y. (2009). DasarDasar Manajemen Keuangan. Salemba Empat.

Erawati, T., \& Sihaloho, D. M. (2019). Pengaruh Struktur Modal, Kinerja Keuangan, Pertumbuhan Perusahaan, Dan Kebijakan Dividen Terhadap Nilai Perusahaan (Studi Empiris Pada Perusahaan Manufaktur Subsektor Makanan Dan Minuman Yang Terdaftar Di Bursa Efek Indonesia Tahun 2012 - 2017. Jurnal Akuntansi Pajak Dewantara, 1(1), 113-128. 
https://doi.org/10.24964/japd.v1i1.89 6

Erich A. Helfert. (1997). Teknik analisis keuangan. Erlangga.

Harmono. (2016). Manajemen Keuangan Berbasis Balanced Scorecard Pendekatan Teori, Kasus, dan Riset Bisnis. Bumi Aksara.

Husnan Suad dan Pudjiastuti Enny. (2015). Dasar-Dasar Manajemen Keuangan. UPP STIM YKPN.

Jogiyanto Hartono. (2003). Teori Portofolio dan Analisis Investasi. BPFE.

Kumalasari Andini, W. D. (2017). Pengaruh Good Corporate Governance Dan Kebijakan Dividen Terhadap Nilai Perusahaan LQ 45. EJournal Sekolah Tinggi Ilmu Ekonomi Indonesia (STIESIA), 6(6), 1-20.

Lolowang, Y. C., \& Hastuti, R. T. (2019). Pengaruh Growth , Kebijakan Dividen, Leverage, Profitability Pada Perusahaan Manufaktur. I(2), 533-542.

https://journal.untar.ac.id/index.php/j $\mathrm{pa} /$ article/view/5025

Musthafa. (2017). Manajemen Keuangan. ANDI.

https://doi.org/10.31227/osf.io/kdtfj

Prasetyo, A. H. (2011). Valuasi Perusahaan. PPM.

Rahmawati, I.A., Rikumahu, Brady., dan Dillak, V. J. (2017). Pengaruh Dewan Direksi, Dewan Komisaris, Komite Audit Dan Corporate Social Responsibility Terhadap Kinerja Keuangan Perusahaan (Studi Kasus Pada Perusahaan Sub Sektor Pertambangan Batu Bara Yang Terdaftar Di Bursa Efek Indonesia Tahun 2013-2015). Jurnal Akuntansi Dan Ekonomi, 2(2), 54-70.

Samsul, M. (2006). Pasar Modal \& Manajemen Portofolio - Google Buku. In Erlangga. Erlangga.

Sugeng, B. (2017). Manajemen Keuangan Fundamental - Google Buku. Deepublish.

Suryandani, A. (2018). Pengaruh
Pertumbuhan Perusahaan, Ukuran Perusahaan, Dan Keputusan Investasi Terhadap Nilai Perusahaan Pada Perusahaan Sektor Property Dan Real Estate. BMAJ: Business Management Analysis Journal, 1(1), 49-59. https://doi.org/10.24176/bmaj.v1i1.26 82

Sutedi Adrian. (2011). Good Corporate Governance. Sinar Grafika.

Wijaya, D. (2017). Manajemen Keuangan Konsep Dan Penerapannya (p. 1). PT Grasindo.

www.idx.co.id. Laporan Keuangan

Tahunan 2015, 2016, 2017, 2018 dan 2019

\section{PROFIL SINGKAT}

Rika Kartika, lahir di Serang, 31 Desember 1990, menyelesaikan pendidikan strata satu Program Studi Teknik Industri di Institut Teknologi Nasional Bandung, lulus tahun 2013 dan menyelesaikan pendidikan Magiter Akuntansi di Universitas Sultan Ageng Tirtayasa, lulus tahun 2016. Saat ini menjadi Dosen Tetap Program Studi Akuntansi, Fakultas Ekonomi dan Bisnis di Universitas Bina Bangsa, SerangBanten.

Ibrohim, lahir di Serang, 10 Agustus 1974, menyelesaikan pendidikan strata satu Program Studi Jurusaan Akuntansi di STIE Widya Wiwaha Yogyakarta, lulus tahun 1999, dan menyelesaikan pendidikan Magiter Akuntansi di Universitas Esa Unggul Jakarta, lulus tahun 2017. Saat ini menjadi Dosen Tetap Jurusan Akuntansi, Fakultas Ekonomi dan Bisnis di Universitas Bina Bangsa, Serang-Banten.

Sona, lahir di Cilegon pada tanggal 21 Nopember 1998 dan menyelesaikan pendidikan strata satu Program Studi Akuntansi di Universitas Bina Bangsa (UNIBA) Serang-Banten dan lulus pada tahun 2020. 